\title{
RICE SUPPLY CHAIN IN THE ZERO AREA OF RICE PLANTS
}

\author{
Suparman*, Nersiwad, Darman \\ Faculty of Economics, University of Tadulako, Indonesia \\ *E-mail: suparman.untad@gmail.com
}

\begin{abstract}
This study aims to analyze the rice supply chain in the area of zero rice plants on Banggai Laut, Central Sulawesi, Indonesia. The study uses survey methods based on rice supply chains. The results of the study found that the rice supply chain to Banggai Laut through four stages using land and sea routes between regencies and provinces. The rice supply chain uses 3 to 7 days. The rice supply chain suppliers in four stages consist of farmers - traders wholesalers - agents - retailers - people. Price gap from farmer to people is IDR 7,000 or almost $100 \%$ of the buying price of rice in the small islands of Banggai Laut. This condition causes low access to rice for the people.
\end{abstract}

\section{KEY WORDS}

Supply chain, rice, island region, Banggai Laut.

Central Sulawesi of Indonesia is a priority area for food insecurity, especially Banggai Laut District which is an autonomous region that does not have rice production (Statistics of Banggai Laut Regency, 2017). The results of the study (Suparman et al. 2013) on food insecurity in the archipelago in Central Sulawesi, found that the main factors causing vulnerability and food insecurity were low food production and people access to food because of the typology of the region which consisted of islands.

The availability of rice food in Banggai Laut is a supply from outside the area by land and sea which is then distributed to the islands to meet the food needs of the people These conditions greatly span the risk of distribution (supply chain) to get to the people, so that it can cause scarcity and high prices of rice. Finally, it has an impact on the occurrence of people food insecurity and conflict.

One approach to addressing the scarcity of agricultural commodities is the implementation of supply chain management, especially by integrating aspects of productionconsumption-distribution (Rani, 2014). Supply chain management is a set of methods and approaches to improve integrity and efficiency between suppliers, manufacturers, warehouses and shops so that merchandise can be produced and distributed to consumers accurately both in terms of quantity, location and time (Simchi-Levi \& Kaminsky, 2000). Supply chain performance is the ability of the supply chain to deliver the right product to the right location at the right time with the lowest logistics costs (Zhang and Okoroafo, 2015).

\section{LITERATURE REVIEW}

Food and Agriculture Organization of the United Nation (1992) defines food security as access to every household or individual to obtain food at all times for the needs of healthy living. In general, food security covers 4 aspects, namely sufficiency, access, security, and time (Baliwaty, 2004). With this aspect, food security is seen as a system, which is a series of three main components, namely food availability and stability, food accessibility and food utilization.

Supply chain management is a tool to integrate the efficiency of suppliers companies, distributors, retailers, so that these tools can produce and deliver products with the right amount, location and time to increase satisfaction in customer service (Indrajid and Djokopranoto, 2002). Chapman et al. (2002) suggested that supply chain risk management focuses on how to understand and overcome chain effects when a large or small accident occurs at a point in the supply network. 
Geary et al. (2002) suggest that uncertainty in a supply chain can stem from consumer, supplier, process and control demands. Uncertainty originating from consumer demand and related to lead time, both from suppliers and customers is the sources of dissatisfaction between elements in the supply chain. Therefore, these two sources of uncertainty need to be managed well so that the element relationships in the supply chain remain stable in order to increase or maintain the level of service to consumers.

\section{METHODS OF RESEARCH}

This research was conducted by survey method through direct observation to the rice distribution channel in the Banggai Laut region. Banggai Laut is a district in Central Sulawesi that does not have rice production. Rice supply chain analysis is based on the distribution flow based on the initial to the last stage. Analysis of the distribution of rice through land and sea transportation so that it reaches the people.

\section{RESULTS AND DISCUSSION}

The population of Banggai Laut is 68,124 people with an area of $725.67 \mathrm{Km}^{2}$ (Statistics of Banggai Laut Regency, 2017). Large population with geographical conditions in the archipelago causes food insecurity (rice). During this time, the community gets rice outside the area. Rice comes from rice producing areas in Central Sulawesi and South Sulawesi. This condition causes high community food dependence on other regions. The following is a rice supply chain in the Banggai Laut region.

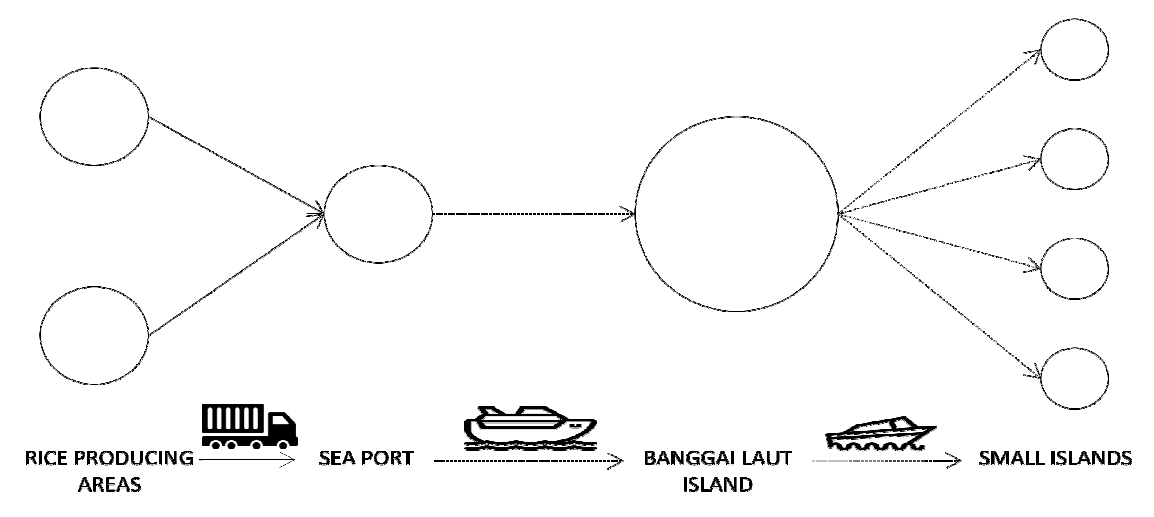

Figure 1 - Rice Supply Chain to Banggai Laut (Source: Survey data, 2018)

Rice supply chain (transportation) to Banggai Laut through four stages using land and sea routes between regencies and provinces:

- Stage 1: Rice is sourced from rice producing areas in Central Sulawesi and South Sulawesi using land transportation;

- Stage 2: Loading rice in the Luwuk Sea Port to Banggai Laut;

- Stage 3: Rice arrives in the capital city of Banggai Laut;

- Stage 4: Distribution of rice to small islands.

The four stages of the rice supply chain use 3 to 7 days. Suppliers of rice supply chains in four stages consist of farmers - collectors - wholesalers - agents - retailers - people.

Table 1 - Price Gap for Rice Between Suppliers

\begin{tabular}{|c|c|c|c|c|c|c|c|}
\hline \multicolumn{2}{|c|}{ Suppliers } & Price / Liter (IDR) & \multicolumn{5}{|c|}{ Price Gap (IDR) } \\
\hline 1 & Farmer & 8,000 & & \multirow{3}{*}{1,000} & \multirow{4}{*}{2,000} & \multirow{5}{*}{5,000} & \multirow{6}{*}{7,000} \\
\hline 2 & Wholesaler & 8,500 & 500 & & & & \\
\hline 3 & Big traders & 9,000 & & & & & \\
\hline 4 & Agent & 10,000 & & & & & \\
\hline 5 & Retailers (City center ) & 13,000 & & & & & \\
\hline 6 & Retailers (Small islands ) & 15,000 & & & & & \\
\hline
\end{tabular}

Source: Survey data, 2018. 
The rice needs of the people in Banggai Laut amount to $\pm 7,460$ tons per year. The price of rice (ordinary type) in Banggai Laut is quite expensive because of the length of the rice supply chain. Price gap from farmer to community is Rp. 7,000 or almost $100 \%$ of the selling price of rice in the small islands of Banggai Laut. This condition causes low access to rice for the people.

\section{CONCLUSION}

The rice supply chain to Banggai Laut through four stages using land and sea routes between regencies and provinces. The rice supply chain uses 3 to 7 days. The perpetrators of the rice supply chain in four stages consist of farmers - collectors - wholesalers - agents retailers - people. Price gap from farmer to community is IDR 7,000 or almost $100 \%$ of the selling price of rice in the small islands of Banggai Laut. This condition causes low access to rice for people.

\section{REFERENCES}

1. Baliwaty Y. F. 2004. Introduction to Food and Nutrition, Swadaya Publisher, Jakarta.

2. Chapman, P., Christopher, M., Juttner, U., Peck, H. \& Wilding, R., 2002. Identifying and managing supply chain vulnerability. Logistics \& transport focus: The journal of the Institute of Logistics and Transport 4: 59-64.

3. Food and Agriculture Organization of The United Nation. 1992. Nutrition and Development a Global Assessment, International Conference on Nutrition, Rome.

4. Geary, S., Childerhouse, P., and Towill, D. 2002. Uncertainty and the seamless supply chain. Supply Chain Management Review 6 (4), 52-60.

5. Indrajid, R. R. \& Djokopranoto. 2002. Supply Chain Management Concept: A New Way to Look at the Supply Chain of Goods. Jakarta: Grasindo, PT Gramedia Widiasarana Indonesia Publisher.

6. Rani, H. 2014. Integration of Supply Chain of Agricultural Commodities. Supply Chain Indonesia. Retrieved from http://supplychainindonesia.com on July 13, 2018.

7. Simchi-Levi, D. \& Kaminsky, P. 2000. Designing And Managing The Supply Chain: Concept, Strategies, And Case Studies. Singapore: McGraw-Hill Higher Education.

8. Statistics of Banggai Laut Regency. 2017. Banggai Laut Regency in Figure 2017, Banggai-Central Sulawesi

9. Suparman, Nersiwad, Kalvin, A. P. 2013. Study of Food Prone Areas in Tojo Una-Una Regency, Central Sulawesi. Research Report. Tadulako University.

10. Zhang, H. \& Okoroafo, S. C. 2015. Third-party logistics (3PL) and supply chain performance in the Chinese market: a conceptual framework, Engineering Management Research 4(1): 38-48. 